ISSN No. 0974-035X

An Indexed, Refereed \& Peer Reviewed Journal of Higher Education Towards Excellence UGC-HUMAN RESOURCE DEVELOPMENT CENTRE, GUJARAT UNIVERSITY, AHMEDABAD, INDIA

\title{
INVESTIGATE COMPETENCY LEVEL OF READING ABILITY AMONG HIGHER SECONDARY STUDENTS' OF TRIBAL TERRITORIES OF GUJARAT
}

\author{
Prof. Dr. Jagdish Joshi \\ \&
}

Mr. Tapan Shah

\begin{abstract}
$\underline{\text { Abstract: }}$
Reading is wonderful that leads human to establish information. In this perspective reading goes with the term proficiency that alludes to person's capacity to be fruitful reader and writer. To be proficient is renowned tag of human. Despite the fact that reading and education go inseparably, in the meantime they vary with one another. Reading is an action though education is capacity. As the word proficiency incorporates reading aptitude, it clears that a person's capacity to take care of issue, surmise thought and perceive printed words. To view in context students of tribal area should posses Reading Skill.
\end{abstract}

Key Words: Reading, Proficiency, Tribal area, Perceive, Literacy

\section{Introduction}

Reading is such an important skill now days and must to acquire. It is complex cognitive process of decoding symbols in order to construct or derive meaning. It is a complex interaction between 
Towards Excellence: An Indexed, Refereed \& Peer Reviewed Journal of Higher Education / Dr. Jagdish Joshi \& Mr. Tapan Shah / Page 66-74

the text and the reader which is shaped by the readers' prior knowledge, experiences, attitude and language community which is culturally and socially situated. It is a skill used to every day and all day. It helps individuals to stimulate the mind and grow mentally. Reading is an important skill to be master because it applies knowledge which is core key of power and bridge between educated to uneducated. It is like an exercise for your mind. It helps your brain to grow strong and healthy. "We learn to read by reading, not through drill and practice, but by free volition, and in this way learners become readers."(Kreshan, 24).Reading opens one mind for new ideas and allows one to view things from different perspective.

Reading is to get to know the crux of the passage and decode the passage into same method. People read text mainly for two reasons, one for pleasure and second for getting information. Currently most reading is either of the printed words from ink or toner on paper, such as book, magazine, newspaper, leaflet, electronic display etc. Handwritten text may also be produced using graphite pencil or a pen. Readers can take different forms of reading according to their purpose or intention. Practice of reading enhances competency among readers' at the different stages. It is remarkable to note that the students at different class must have reading competency of English language. Reading competency means the level of the reader who can grasp the meaning of printed word and understand the core idea of the passage. It can also define as the ability to read critically and thoughtfully. "Sustainable development and social cohesion depend critically on the competencies of all of our population with competencies understood to cover knowledge, skill, attitudes and values." (OECO-4) Hence, reading comes under the four skills of language learning the development of this skill must be captivated while delivering information in classrooms. Gujarat State Education Board has been exclusively focusing on reading skill in English language at Higher Secondary i.e $11^{\text {th }} \& 12^{\text {th }}$ board. "This text has retained the earlier format of having two sections. The first section provides reading materials in the form of speeches, stories, biographical sketches, plays, poems and articles while the second section, of course, a shorter one in size, has reading material for extensive reading”. (GSHEB) Practice of reading develops readers' ability to communicate with text and help to approach to their expected information. Various forms of reading are being used by reader to read text. These forms are also seen among students of different classes. It can identify by observing how reader read the text. These various forms of reading are mention below. 
1. Skimming

2. Scanning

3. Intensive

4. Extensive

5. Loud reading

6. Silent reading

7. Inferring

Out of any of these form can be seen among students at higher level. Generally, students at higher secondary are not proficient to read the text in L2 comparatively to the other urban districts.

\section{Skimming:}

Skimming refers a process or techniques of reading speed. It means running the eyes over text quickly, to get the gist. Skimming is a process of reading speed that involves visually searching clue of the sentences on a page. For some students it comes naturally and may not be acquired by practice. "Speed reading programs are available through courses, both in person or software based, and manuals. While the average adult reading rate is 250 words per minute with $70 \%$ comprehension, speed reading programs typically claim that improvements to 500 words per minute or more while maintaining or improving comprehension is possible". (Smith, Brenda 98) Skimming is usually seen more in adults than in children. It is conducted at a higher rate than normal reading for comprehension and result in lower comprehension rates, especially with information rich reading material. Another form of skimming is that commonly employed by readers on the web. This involves skipping over text that is less interesting or less relevant. This form of reading is not new but has become increasingly prevalent due to the ease with which alternative information can be accessed online. Skimming is a process of rapid reading with concentrating on absorbing all the details. Skimming can give you overview of the Para it doesn't mean reader go through to the word to word meaning. Reader might read the title, subtitle, subheading and illustrations. Skimming is very useful to find dates, names, and places. It might be used to review graphs, tables and charts. 


\section{Scanning:}

Scanning generally means to look for a particular piece of information. It can be purposeful reading. Reader scans his eyes on paper and find out the desirable information from printed pages. It means reader is searching for a word or idea reader knows for what he is looking for? Once reader scan the abstract then he decided to go back to the skimming.

\section{Intensive:}

Intensive Reading can include reading with the aim and with interest. It focuses on the comprehend reading. Reader with this reading goes through the vocabulary, Structure pattern, Grammar and also gist of the passage. This reading covers ease of language reading. "Intensive reading that the readers take a text, study it line by line and refer at very moment to the dictionary about the grammar of the text itself" (Palmer 91). It is basically a study technique for organizing reading which will have to be understood and remembered. One may have good command over comprehensive reading.

\section{Extensive:}

Extensive reading is the reading for pleasure or enjoyment. "It is generally associated with reading large amounts with the aim of getting an overall understanding of the material. Readers are more concerned with the meaning of the text than the meaning of individual words or sentences." (Bam ford and Day 117) It only deals with the whole meaning of the passage not with word by word meaning.

\section{Loud Reading:}

Loud reading simply means to read the text aloud. It enhances readers' intonation, pronunciation and accent. Listeners get benefit to hear right pronunciation word. "It provides children with a demonstration of phrased, fluent reading." ( Fountas \& Pinnell 83 ) 


\section{Silent Reading:}

Silent reading goes with the reading in mind. Silent reading is also called intensive reading in which reader can read with an understanding and concentration. It is primary mode of reading for proficient readers.

\section{Inferring:}

Inferring means guessing meaning of a text. It is the process of creating meaning from text. It combines the prior knowledge with what is being read. Readers use previous knowledge, experience and psychology to understand the text. The reader reads between the lines to pick up on clues provided by the author in order to extract the meaning. "Readers think about and search the text, and sometimes use personal knowledge to construct meaning beyond what is literally stated" http://reading.ecb.org/teacher/inferring/index.html)

Having discussed on different forms of reading it is recommended that students should pave the knowledge of competence reading. Reading competency means the level of the reader who can grasp the meaning of printed word and understand the core idea of the passage. It can also define as the ability to read critically and thoughtfully.

In Gujarat English has been compulsory from std. V since 1960. Though, the state's rural districts of higher secondary students facing problem of reading in English. Tribal areas students do not have competency in reading. They are not able to crux the meaning of the text properly.

In concern with the issue researcher decides to explore the competency or reading in tribal area Gujarat. The students' reading competency has been carried out with different tests and methodology in tribal areas higher secondary school.

An analysis of the responses represents that students are not able to comprehend the printed text at tribal district Schools. The errors in Reading which are shown in their performance makes it clear that the respondents having problem in comprehend the printed text. During the scrutiny of the activities, the researcher has found so many 
Towards Excellence: An Indexed, Refereed \& Peer Reviewed Journal of Higher Education / Dr.

Jagdish Joshi \& Mr. Tapan Shah / Page 66-74

wrong answers given by respondents. The activities were up to their level but they are not

able to respond as indented response to questions. Respondents are not able to identify the all the chunks which placed on the text. Students are facing problems while performing due to disability to identify the cohesive and content of the passage.

Moreover, It is shown that the respondent have ample command with Scanning. During performing scanning activity they had answered all the questions with in stipulated time in all schools. The Highest percent of students develop their skill in scanning, 29\% students have enough comprehend skill in Scanning.

Under Skimming activity researcher scrutinize pedagogies were not comprehend the text as intended response. They were facing problem to identify some terminology of the text whereas the text based on the well-known stories. Only $24 \%$ studnts can tackle the activity perfectly and within given time period from all three schools.

Apart from that, under Loud Reading only $24 \%$ students can get fluency which is parallel percent to Skimming Skill. Researcher has marked during testing this activity that most of respondent were hesitate to read aloud. Activity was based on the poem under which researcher scrutinizes their pronunciation, intonation, and word recognize power. Initially majority pedagogies were not responding in this activity due to shyness to read aloud among others students. Then they read the poem and complete the task.

Moreover, Silent Reading has made good test to comprehend their reading skill. Respondent feel ease to give answer in that but somewhere they faced some problem to identify jargon which used in the passage. Expertise over word recognizes is a fundamental requirement to have reading flavor. Furthermore, the respondent made mistake in comprehend the passage apart from $23 \%$ students' response the activity.

\section{Conclusion}

As a result of the study it is revealed that the majority of the students obtained less skill to identify the main idea from the text. As per data analyses the sample schools were 
Towards Excellence: An Indexed, Refereed \& Peer Reviewed Journal of Higher Education / Dr. Jagdish Joshi \& Mr. Tapan Shah / Page 66-74

average in reading proficiency. Investigator has evaluated and come on the conclusion on the basis of gained score during the study that students were not able to comprehend the printed word at higher secondary. Students have a less understanding in finding supporting details as compared to extract main idea from the text. An average expected reading speed of the higher secondary school students is 200 words per minutes. But, as evaluation data says that students of higher secondary schools are not as efficient to read the text as expected in tribal area. Their performance to identify the words is poor and not clear. Students at this stage facing problems to grab the meaning due to disability to identify the cohesive of the passage. To read a word or text the students ought to have abilities of word recognition, proper pronunciation and scanning in L2 language which are not visible in tribal areas students. As regards the sub skills of reading comprehension few students' scores were better in identifying the main idea from the test. Students showed the average performance amongst tribal schools. It is found that students respond to the text less effective and less appreciative. They hardly make effort to strengthen their level of reading English as second language. They do not cultivate habit of reading English. i.e. News Paper, Magazines, and extra materials etc. students were unable to comprehend the printed words. They did not have clear understanding of the jargon used in the text. It was manifested from their responses. Their attitude towards reading second language was not seen positive. Students were not having fluency in reading English due to lack of explore and motivation. Students at initial stage get nervous or feeling unsecure in classroom while they were asked to read the aloud. So, Class room atmosphere for language learning also seen dull. The analyses data indicates students of tribal areas are not feel ease with second language especially in reading skill.

To promote reading skill and eliminate the threat of reading disabilities among rural students it is recommend to focus on skillful devised policies that help teachers' allegiance and provide them with skills and resources necessary for them to perform well in difficult circumstances may contribute to improved classroom result and thus to improved reading achievement . 
Towards Excellence: An Indexed, Refereed \& Peer Reviewed Journal of Higher Education / Dr. Jagdish Joshi \& Mr. Tapan Shah / Page 66-74

\section{Reference:}

Anderson and Urquhart. Reading in a Foreign Language. London: Longman.1984.print.

Bam,ford and Day.Extensive Reading in the Second Language Classroom. Cambridge: Cambridge University Press.1997.Print

Bloomfield,Leonard and Barnhart Clarena. Let's Read: A Linguistic Approach. Michigan: Wayne State University Press.2001.Print.

Fountas,I.C and Pinnell.G.S. Guided reading: Good first teaching forall children. Portsmouth: Heinemann.1996.Print.

Grellet, Francoise. Developing Reading Skill: A Practical Guide to Reading Comprehension Exercises. Cambridge: Cambridge University Press.2003.Print.

Gujarat Government. English second language. Gandhinagar: Gujarat State Board of School Text Book Press, 2010. Print.

Kreshan, S The Power of Reading: Insight from the research. Englewood: Libraries Unlimited. 1993.Print.

Matthews ,Bob and Ross,Liz. Research Methods a Practical guide for the Social Sciences. Canada : Pearson Education Canada.2010.Print.

Mc Arthur, Tom. The Oxford Guide to world English. Oxford: Oxford University Press, 2002. Print.

OECD. The Definition and Selection of Key Competence executive Summary. OECD Pub, 2005.Print.

Richard, jack and Richard, Schmidt. Longman Dictionary of Language Teaching and Applied Linguistics. 4thed. 2010. Print.

Smith, Brenda D. Breaking Through: College Reading. 7thed. London: Longman.2004.Print.

\section{Web Sources}

Competency.www.businessdictionary.com.N.p.N.d.web.07Jan 2019

www.reading.ecb.org teacher/inferring/index.web. 30 Jan 2019. 


\section{Dr. Jagdish Joshi \\ Professor-Director \\ UGC-Human Resource Development Centre Gujarat University, Ahmedabad}

\&

\section{Mr.Tapan P.Shah}

Ph.D Research Scholar, Gujarat University,Ahmedabad

Assistant Prof. Aroma College of Commerce

Usmanpura, Ahmedabad.

tpnshah87@gmail.com 